\title{
"7C" principle and "Alcohol" method towards persevering control of COVID-19 infection in China
}

\author{
Linghang Wang* \\ Emergency Department of Infectious Diseases of Beijing Ditan Hospital, Capital Medical University, Beijing, 100015, China
}

\section{Communication}

2020 spring festival was and will be the most impressive festival to all Chinese people, due to the bitter memories but extraordinary courage to fight against the PHEIC announced by WHO on Feb $4^{\text {th }}$. Chinese scientists confirmed the pathogen in a very short time and Chinese government take enormous efforts to control the epidemic, locking down Wuhan and Hubei Province, dispatching thousands of medical doctors and nurses to Hubei to reduce the disease burden on local medical system. Many of them on the ground level work seven days a week without a break; the happy time accompanying with "alcohol" seems far away from their daily life, even COVID-19 cannot tolerate $75 \%$ ethanol.

The novel coronavirus pneumonia is far beyond our conventional judgement because it can not only cause high fatality in those older people and patients with underlying disease, but also can cause mild disease, sometimes even asymptomatic infection. The combination of hard recognition of the infection and high mortality in vulnerable groups has posed a huge challenge to the complete control in current fighting against the outbreak in China. Here, we propose " $7 \mathrm{C}$ " principle (Table 1) (working hard seven days a week without break) and "alcohol" (Table 2) (maybe the sterilization or the final celebrating drink) measure aiming at summarizing the current control efforts.

The novel coronavirus epidemic has posed a great challenge to the destiny of whole humankind. Chinese people have made huge efforts with giant sacrifice to contain the virus from spreading to all over

Table 1. 7C principle

Origin of the novel virus; the best control strategy; the comprehensive characteristics of the emerging disease, the accurate spectrum of the

Critical thinking infection, all the potential transmission route; the virus shedding duration of a convalescent patient, all the evidence need to be accumulated to guide and modify current prevention and management strategy.

Communication Chinese government with WHO; Government with general people;

Cooperation between different research units; $\mathrm{CDC}$ with clinical hospitals; commercial Cooperation company with academic institutes; authorities with the media; etc.

As for Hubei province (epidemic center), the current priority aim is to reduce the peak of disease burden and fulfill the requirements of admitting all severe patients, quarantining all the infectious cases.

$\begin{array}{ll}\text { Coordination } & \text { For those provinces outside of Hubei, the main target is meticulous }\end{array}$ screening any suspect case and preventing the possible outbreak, especially in Health care settings.

The decision of locking down the city, lock down Hubei province;

Creativity joint prevention and control measures in communities; traditional Chinese medicine to treat the cases; etc.

Defeating COVID-19 outbreak becomes the priority of the whole country, even the entire world: doctors save lives, researchers study the mechanism

Concentration $\quad \begin{aligned} & \text { and pathogen characteristics, medicine and vaccine. General people } \\ & \text { and }\end{aligned}$ follow the instruction, stay home; nearly all people wear masks.

Consensus must be achieved to overcome the rumors, panic, stigma

Consensus and misleading information. Efforts need to be put into the final successful control of this outbreak.
Table 2. "Alcohol" principle

\begin{tabular}{|l|l|}
\hline Administration & $\begin{array}{l}\text { All the strategies and measures are executed level by level depending } \\
\text { on the strong and strict administration system. Big new hospitals built } \\
\text { in 10 days; square hospitals used in a short time. Grid management } \\
\text { implemented in communities. }\end{array}$ \\
\hline Logistics & $\begin{array}{l}\text { Tons of masks and other PPE need to be sent to Hubei Province, all } \\
\text { the medical equipment and daily life necessities are guaranteed by the } \\
\text { strong and fast logistic system. }\end{array}$ \\
\hline Communication \\
Cooperation & $\begin{array}{l}\text { Chinese government with WHO; Government with general people; } \\
\text { between different research units; CDC with clinical hospitals; } \\
\text { commercial company with academic institutes; authorities with the } \\
\text { media; sharing the date and information; sharing the experiences, etc. }\end{array}$ \\
\hline Orientation & $\begin{array}{l}\text { In and outside of Hubei Province, the main work orientation is } \\
\text { different. In the epidemic center, the main purpose is to decrease } \\
\text { the mortality of severe patients and eliminate the transmission in } \\
\text { communities as much as possible, Outside of Hubei province, } \\
\text { the main target is a defending war: screening any suspect case and } \\
\text { preventing the potential risk of outbreak. }\end{array}$ \\
\hline Health system\& & $\begin{array}{l}\text { Thousands of health system staff, especially the doctors and nurses } \\
\text { from infections department, respiratory department, intensive care } \\
\text { department have been sent to Wuhan and Hubei province to enhance } \\
\text { the power of local saving lives work, to help decrease the mortality } \\
\text { and solve the problem of the scarce of local health system resource. } \\
\text { humanism is also paid much attention, for the care of other patients } \\
\text { who have the common medical needs in this specific period. }\end{array}$ \\
\hline Leadership & $\begin{array}{l}\text { Tons of rescue facilities and equipment need to be shipped to Wuhan, } \\
\text { communities need to be educated and controlled; square hospitals for mild } \\
\text { cases, severe cases sent to those designated hospital for intensive care. }\end{array}$ \\
\hline Organization & $\begin{array}{l}\text { The powerful leadership is the decisive factor to fight against the } \\
\text { COVID-19 epidemic in China by Chinese government. Worldwide } \\
\text { speaking, by WHO. }\end{array}$ \\
\hline &
\end{tabular}

the world. Implementing the " $7 \mathrm{C}$ " principle and "alcohol" measures mentioned above, Chinese have set a paradigm to control the epidemic.

\section{Author introduction}

Director of emergency department of Beijing Ditan Hospital, which is the designated hospital for admitting COVID-19 patients in Beijing.

Copyright: (C2020 Wang L. This is an open-access article distributed under the terms of the Creative Commons Attribution License, which permits unrestricted use, distribution, and reproduction in any medium, provided the original author and source are credited.

${ }^{\star}$ Correspondence to: Linghang Wang, Emergency Department of Infectious Diseases of Beijing Ditan Hospital, Capital Medical University, Beijing, 100015, China, E-mail: linghang.wang@ccmu.edu.cn

Received: April 10, 2019; Accepted: April 16, 2020; Published: April 20, 2020 